\title{
Correction to: Two new species of Cardicola (Trematoda: Aporocotylidae) from the damselfish Abudefduf whitleyi (Perciformes: Pomacentridae) and the triggerfish Sufflamen chrysopterum (Tetraodontiformes: Balistidae)
}

\author{
Russell Q-Y. Yong ${ }^{1} \cdot$ Scott C. Cutmore ${ }^{1} \cdot$ Thomas H. Cribb $^{1}$
}

Published online: 20 July 2019

(C) Senckenberg Gesellschaft für Naturforschung 2019

Correction to: Marine Biodiversity

https://doi.org/10.1007/s12526-018-0895-4

The arrows or lines are missing from the published Fig. $1 \mathrm{~b}$ and Fig. $1 \mathrm{~d}$ of this article. The correct Fig. 1 is included here. This mistake does not affect the concept or any other information provided in other parts. In addition, the results and conclusions of the paper also remain valid.

The original article has been corrected.

The online version of the original article can be found at https://doi.org/ 10.1007/s12526-018-0895-4

Russell Q-Y. Yong

rqy.yong@uqconnect.edu.au

School of Biological Sciences, The University of Queensland, QLD, Brisbane 4072, Australia 


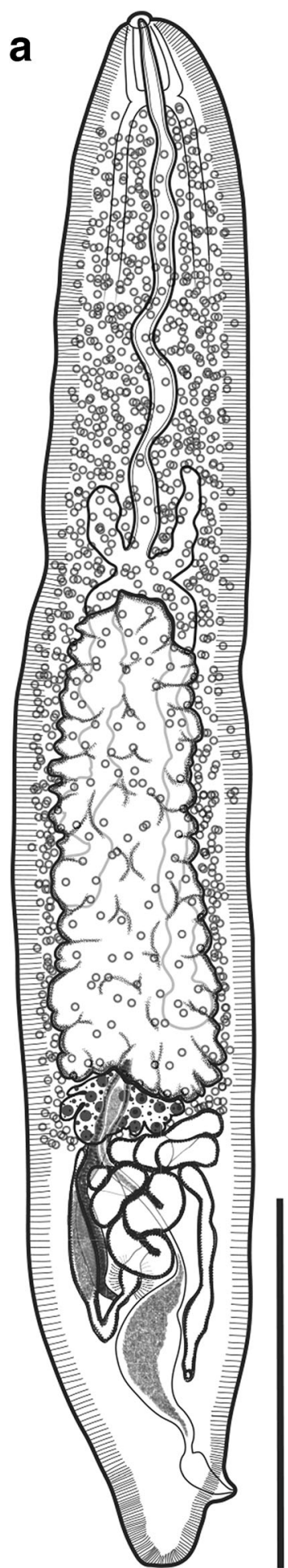

Fig. 1 Two new species of Cardicola. a Cardicola abu sp. n., holotype, ventral view; b Cardicola abu n. sp., holotype, terminal genitalia, ventral view; c Cardicola yuelao n. sp., holotype, dorsal view; d Cardicola yuelao n. sp., holotype, terminal genitalia, dorsal view. Abbreviations:
C

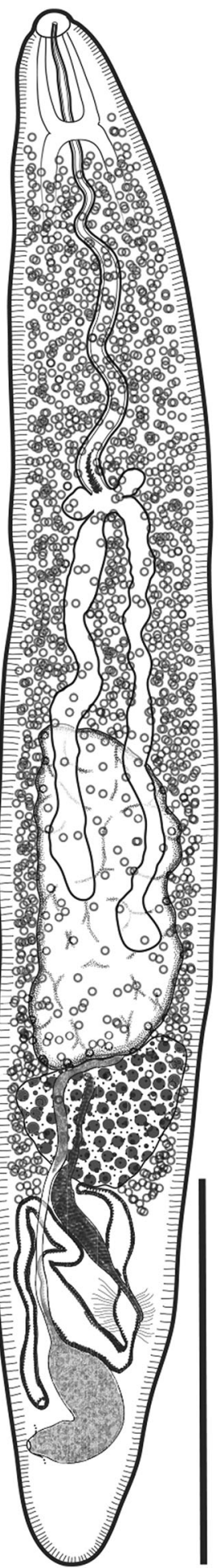

FGP female genital pore, MGP male genital pore, Oo oötype, OSR oviducal seminal receptacle, Ov ovary, PSV primary seminal vesicle, SSV secondary seminal vesicle, SV seminal vesicle, Ut uterus. Scale bars: a, c $200 \mu \mathrm{m} ; \mathbf{b}, \mathbf{d} 50 \mu \mathrm{m}$

Publisher's note Springer Nature remains neutral with regard to jurisdictional claims in published maps and institutional affiliations. 